\title{
DETERMINATION OF THE PHOSPHATE CONTENT ORIGINALLY ADSORBED ON THE SOIL BY FITTING AN ADSORPTION ISOTHERM MODEL
}

\author{
G. FÜLEKY - L. TOLNER* \\ Department of Soil Science and Agricultural Chemistry, \\ University of Agricultural Sciences Gödöllö \\ H-2103 Gödöllö, Hungary \\ *e-mail:TolnerLaszlo@mkk.szie.hu \\ (Received $10^{\text {th }}$ Sep 2005, accepted $10^{\text {th }}$ Oct 2006)
}

\begin{abstract}
In order to replace the rather complicated physico-chemical method, a mathematical technique related to the binding of phosphate ions was elaborated to determine the labile, and thus plant-available phosphate content of the soil.

The technique is based on the analysis of the quantity of phosphate bound to the soil in the equilibrium state when soil samples are suspended in solutions containing various concentrations of phosphate. The majority of soils contain a certain amount of adsorbed phosphate, so negative adsorption is observed if the analysis is carried out with solutions containing little or no phosphate. The isotherm models generally used to describe adsorption processes do not assume the presence of any material originally bound on the adsorbent surface, so their starting point is a state with a zero quantity of adsorbed material on the adsorbent in a solution with an initial equilibrium concentration of zero. In the case of soil phosphate adsorption, however, different results are obtained, as the soil already contains adsorbed phosphate in its original state. For this reason the isotherm model was modified.

The modified isotherm model was fitted to the measurement data using non-linear regression. The quantity of phosphate originally adsorbed on the soil can be calculated using a model parameter. The phosphate quantity calculated in this way exhibits a close correlation both with the isotopically exchangeable phosphate content, and with the results obtained with the best chemical extraction methods.

Keywords: soil, phosphate, adsorption, model
\end{abstract}

\section{Introduction}

Many characteristics of the soil phosphate cycle, such as the maximum adsorbable phosphate quantity, the equilibrium quantity of phosphate, the various binding energies and, of course, the phosphate buffering capacity of the soil, can all be calculated with the help of phosphate adsorption isotherms. In general, the two-term Langmuir isotherm and the Freundlich isotherm models give the best fit to measured data $[2,8,10]$. The quantity of phosphate originally adsorbed on the soil (Q) must be known before either of these isotherms can be fitted [2, 3, 4]. The most accurate way of calculating this is to determine the quantity of isotopically exchangeable phosphate (E) $[2,8,9]$, but this calculation is extremely complicated. For this reason, many authors have attempted to find a simpler way of determining the quantity of phosphate originally adsorbed on the soil, for instance by using the quantity of phosphate extractable in $\mathrm{NaHCO}_{3}$ solution (Olsen-P) [1].

The value of $\mathrm{Q}$ can also be calculated by extrapolating the adsorption curve to 0 equilibrium concentration [6]. However, the Q value determined in this way is greatly influenced by the model applied [4]. 
The Freundlich and Langmuir isotherm models previously applied do not always give a satisfactory fit, so increasingly complicated models with a larger number of parameters have been elaborated, such as the two-term Langmuir isotherm $[8,10]$, the BET isotherm [11].

Although physico-chemical explanations were given for the parameters, the goodness of fit could really be attributed to the flexibility gained by the increase in the number of parameters. However, the real values of the parameters is to provide information on the properties of the soil. This possibility decreases as the number of parameters increases, as the individual parameters cannot be estimated independently of each other. This problem is particularly obvious in the case of samples from the same soil given different treatments [12]. It could be expected that some of the parameters would be constant characteristics of the soil, while others would vary depending on the treatment. However, experience shows that the parameters of multifactorial models do not meet this criterion.

The theoretical problem involved in the independent estimation of coefficients is further aggravated by the practical problem that the fitting of the models is carried out by means of non-linear regression, i.e. by iteration. Most earlier attempts to "linearise" these models also contained errors [12]. The possibility of using a modified Freundlich isotherm (Eq. 1.) with a constant exponent to solve this problem was also examined:

$$
P_{a d s}=k * c^{\frac{1}{n}}-Q
$$

When investigating the adsorption of phosphate on acidic Hawaiian soils, Davis [5] found that the correlation between the phosphate adsorbed on the soil and the concentration of the equilibrium solution could be expressed by a simple radical function. Among the whole root exponents examined $(\mathbf{n}=1,2,3,4)$, the best fit was obtained at a value of $\mathbf{n}=3$, i.e. an index of $1 / 3$. This model was confirmed and applied by the present authors in previous work [12]. Barrow [4] found a value of $\mathbf{n}=2.5$ to be the most suitable.

Hartikainen [7] used phosphate solutions with extremely low concentrations $(0-0.5$ $m g^{*} \mathrm{dm}^{-3}$ ) to calculate the sorption isotherm. In this narrow range the isotherm could be taken as a straight line to a good approximation, i.e. the value of the root exponent was $\mathbf{n}=1$.

The present paper demonstrates that the problem can also be solved in a less restricted manner using a combination of linear and non-linear regression. These relationship help to determine the originally sorbed phosphate content of soil.

\section{Materials and methods}

Phosphate adsorption was examined on three Hungarian soils (Table 1).

As the purpose of this work was determine the quantity of phosphate originally present in the sorbed state by the help of a model, the soils were first treated with phosphate to achieve various levels of originally adsorbed phosphate. In general these treatments involved $0,10,20,40,80,160,320$ and $640 \mathrm{mg} \mathrm{P} / \mathrm{kg}$ soil, achieved by mixing $\mathrm{KH}_{2} \mathrm{PO}_{4}$ into the soil. The treated samples were then incubated at room temperature at constant moisture content for 18 months. 
Table 1. The main characteristics of soils

\begin{tabular}{|c|c|c|c|c|c|c|c|}
\hline Soil No. & Soil type & $\begin{array}{c}\text { Tex- } \\
\text { ture }\end{array}$ & $\begin{array}{c}\mathbf{p H} \\
\mathbf{( K C l})\end{array}$ & $\begin{array}{c}\mathbf{C a C O 3} \\
\mathbf{\%}\end{array}$ & $\begin{array}{c}\mathbf{O M} \\
\mathbf{\%}\end{array}$ & $\begin{array}{c}\mathbf{O l s e n - P}_{\mathbf{m g . k g}} \\
\mathbf{m g}^{-1}\end{array}$ & $\begin{array}{c}\mathbf{E} \\
\mathbf{m g . k g}\end{array}$ \\
\hline Orosháza & $\begin{array}{c}\text { Chernozem, } \\
\text { solonetz in the } \\
\text { deeper layers }\end{array}$ & loam & 7.1 & 1.7 & 3.72 & 8,2 & 17,2 \\
\hline $\begin{array}{c}\text { Hajdú- } \\
\text { böszörmény }\end{array}$ & $\begin{array}{c}\text { Meadow } \\
\text { solonetz }\end{array}$ & $\begin{array}{c}\text { clay- } \\
\text { loam }\end{array}$ & 5.7 & - & 7.73 & 8,8 & 27,3 \\
\hline Örbottyán & Calcareous sand & sand & 7.4 & 3.3 & 1.03 & 8,1 & 15,5 \\
\hline
\end{tabular}

The phosphate quantities adsorbed on the soil samples after the preliminary treatments were determined using two methods, including the measurement of isotopically exchangeable phosphate $(\mathrm{E})$ and the quantity of phosphate extractable with $\mathrm{NaHCO}_{3}$ solution (Olsen-P) (Table 1).

Phosphate adsorption analysis was carried out on the treated samples. In general, the initial concentrations used for adsorption were again $0,10,20,40,80,160,320$ and 640 $\mathrm{mg} \mathrm{P} / \mathrm{kg}$ soil.

All the regression calculations and figures were carried out using the Windows Excel program. The linear regression was carried out with the worksheet function, while the one-parameter non-linear regression combined with this was carried out with a macro written in Visual Basic.

\section{Results and discussion}

The eight levels of originally adsorbed phosphate (Q) achieved on each of the three soils by means of preliminary treatment were determined by fitting adsorption isotherms. The modified Freundlich isotherm (Eq. 1.) model used for the calculations, was linearised using the Eq. 2 equation. For a specific value of $\mathbf{n}$, the model is thus converted to the following linear function (Eq. 3.):

$$
\begin{gathered}
x=c^{\frac{1}{n}} \\
P_{a d s}=k * x-Q
\end{gathered}
$$

where $\mathbf{k}$ gives the steepness of the slope, and $\mathbf{Q}$ the intersection, the absolute value of which gives the quantity of adsorbed phosphate associated with 0 equilibrium concentration, i.e. the quantity of phosphate originally adsorbed on the soil sample.

For a given value of $\mathrm{n}$ the linear regression clearly reveals the $\mathbf{k}, \mathbf{Q}$ parameter pair belonging to the closest fitting model, i.e. that with the minimum value for the sum of squares (SQ) between the measured and calculated values.

Using various values of $\mathbf{n}$, the sum of squares between measured and calculated values (SQ) was calculated using the models evolved with the $\mathbf{k}$ and $\mathbf{Q}$ parameters obtained from linear regression. Depending on the $\mathbf{n}$ values, the values of the sum of squares (SQ) could be plotted on a curve containing a minimum. The search for this single-parameter minimum was carried out using a simple technique, involving a macro 
that finds the optimum $\mathbf{n}$ value with the desired precision using the regression parameters and sums of squares (SQ) automatically generated by the Excel program.

The following adsorption curves were fitted to the data of samples adjusted to the eight different levels of originally adsorbed phosphate by means of preliminary treatment on soil from Orosháza (Fig. 1).

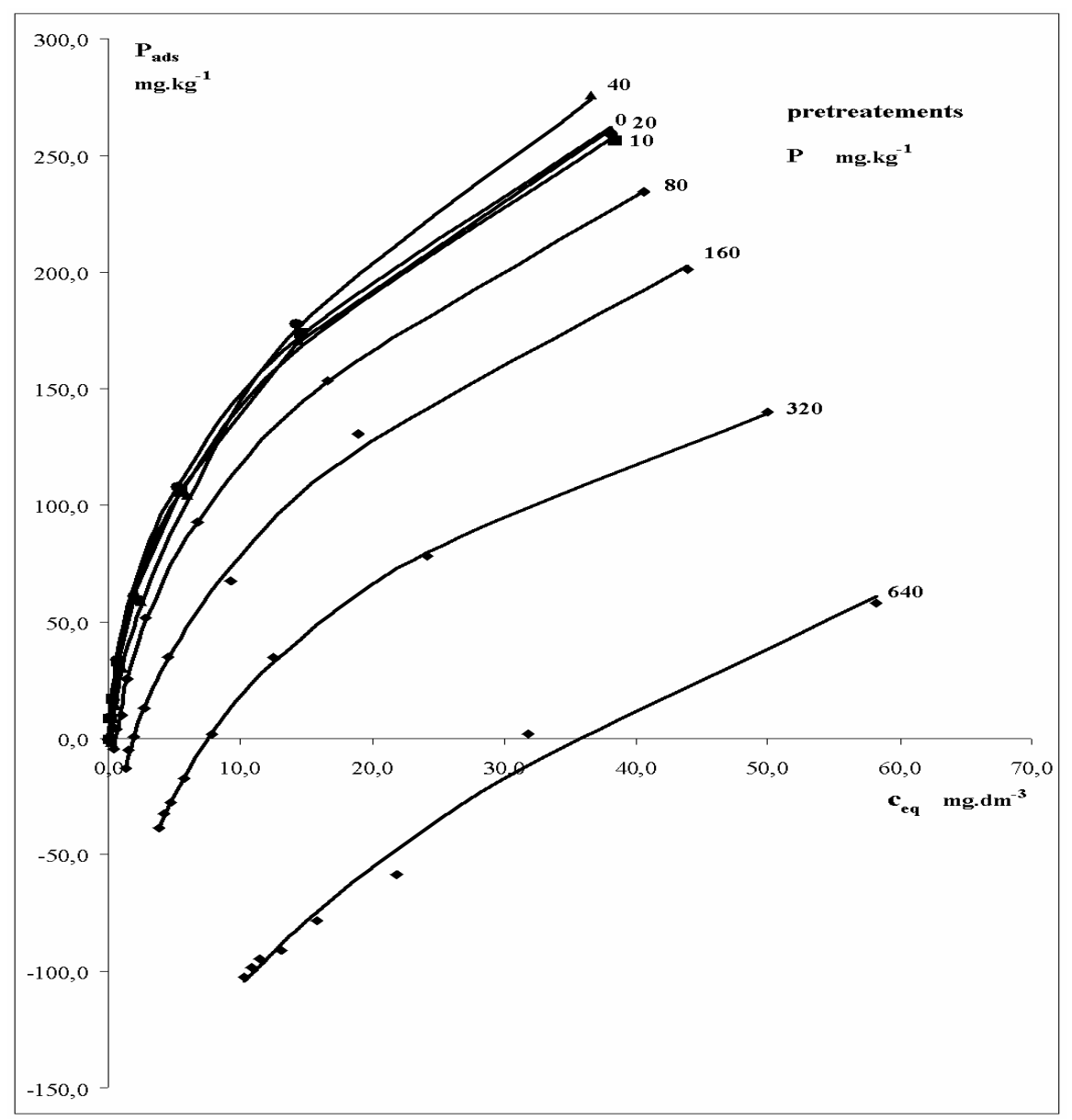

Figure 1. Adsorption isotherms of the pretreated Orosháza soil.

The optimum parameters and the corresponding values of the sum of squares (SQ) are presented in Table 2.

Table 2. The parameters of the model on Orosháza soil

\begin{tabular}{|c|c|c|c|c|}
\hline $\begin{array}{c}\text { Preliminary treatments } \\
\text { mg P/kg soil }\end{array}$ & $\mathbf{n}$ & $\mathbf{k}$ & $\mathbf{Q}$ & SQ \\
\hline 0 & 2.53 & 67.27 & 20.92 & 93.25 \\
\hline 10 & 2.50 & 65.71 & 23.96 & 60.80 \\
\hline 20 & 2.61 & 72.92 & 32.19 & 98.99 \\
\hline 40 & 2.19 & 58.88 & 28.81 & 53.69 \\
\hline 80 & 2.79 & 79.26 & 64.60 & 27.01 \\
\hline 160 & 2.69 & 72.17 & 91.55 & 92.64 \\
\hline 320 & 5.07 & 206.90 & 308.37 & 13.05 \\
\hline 640 & 2.22 & 48.89 & 243.83 & 353.45 \\
\hline
\end{tabular}


The Q values obtained were compared with the $\mathrm{E}$ values representing the isotopically exchangeable quantities of adsorbed phosphate. The correlation was linear (Fig. 2).

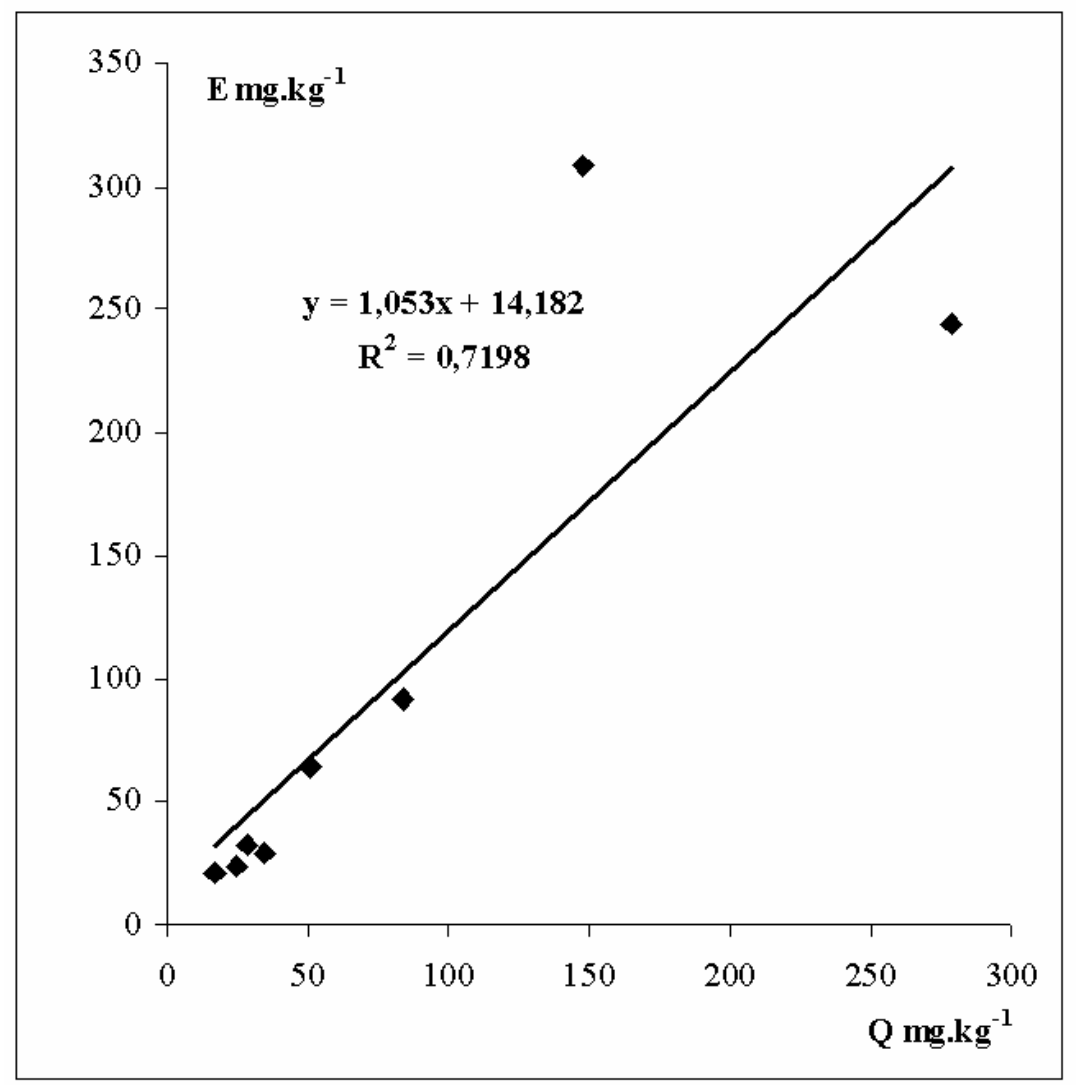

Figure 2. Correlation of $Q$ and $E$ values of Orosháza soil.

The linear function between $\mathbf{Q}$ and $\mathbf{E}$ values (Eq. 4.):

$$
E=a+b * Q
$$

The parameters of linear function and determination coefficients $\left(\mathbf{R}^{\mathbf{2}}\right)$ characteristic of the correlation between $\mathbf{Q}$ and $\mathbf{E}$ values are presented for all three soils in Table 3.

Table 3. Parameters of linear correlation between $\boldsymbol{Q}$ and $\boldsymbol{E}$ values

\begin{tabular}{|c|c|c|c|}
\hline Soil No. & $\mathbf{a}$ & $\mathbf{b}$ & $\mathbf{R}^{\mathbf{2}}$ \\
\hline Orosháza & 14.97 & 1.103 & 0.6419 \\
\hline Hajdúböszörmény & -5.23 & 0.908 & 0.7698 \\
\hline Örbottyán & 1745,9 & 99,117 & 0,0918 \\
\hline
\end{tabular}

The $\mathbf{Q}$ values did not increase as unambiguously as the $\mathbf{E}$ values as the result of preliminary treatment, so the correlation between them was not very close. It can be seen from the $\mathbf{k}$ and $\mathbf{n}$ values (Table 2) obtained during fitting that these values differed considerably for the same soil in different treatments. The deviations were greatest in cases where there were also anomalies in the $\mathbf{Q}$ values. 
In order to solve this problem, it was assumed that the $\mathbf{n}$ values did not differ for different treatments on the same soil, and the Excel worksheets were modified accordingly, the same $\mathbf{n}$ value being applied for the linearisation of all eight treated samples of each individual soil. The best common $\mathbf{n}$ value was determined as described above, by iteration using an Excel macro, except that the value of the sum of squares characteristic of the goodness of fit was formed by summing the values obtained for the eight samples. The parameters and determination coefficients $\left(\mathbf{R}^{\mathbf{2}}\right)$ characterising the correlation between the $\mathbf{Q}$ and $\mathbf{E}$ values are given for all three soils in the following table (Table 4).

Table 4. Parameters of linear correlation between $\boldsymbol{Q}$ and $\boldsymbol{E}$ values using common $\boldsymbol{n}$

\begin{tabular}{|c|c|c|c|}
\hline Soil No. & $\mathbf{a}$ & $\mathbf{b}$ & $\mathbf{R}^{\mathbf{2}}$ \\
\hline Orosháza & 3,56 & 0.950 & 0.9970 \\
\hline Hajdúböszörmény & 14.67 & 0.943 & 0.9993 \\
\hline Orbottyán & -17.16 & 2.185 & 0.8959 \\
\hline
\end{tabular}

The Q values obtained in this way exhibited closer correlation with the E values, as is clearly seen for the Orosháza soil on the following figure (Fig. 3).

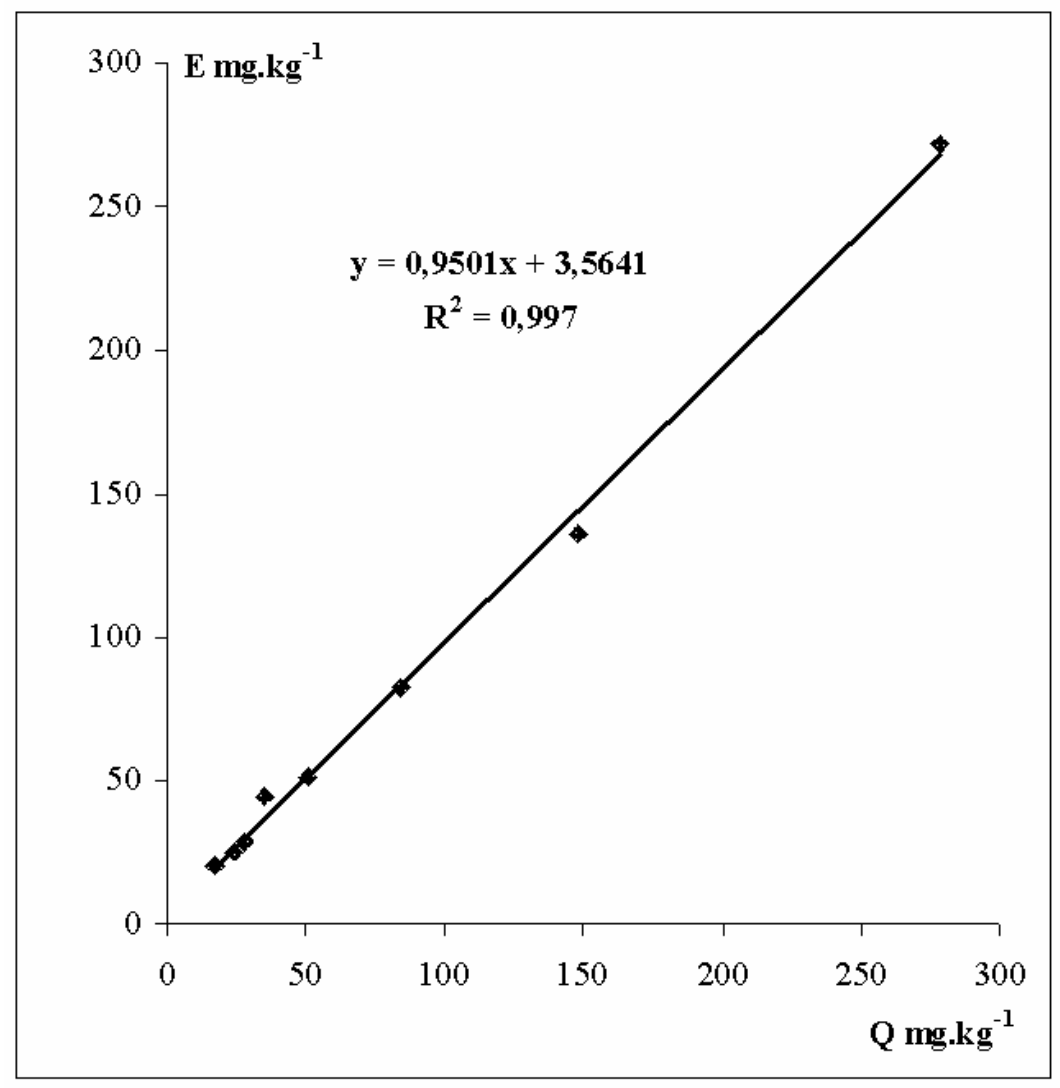

Figure 3. Correlation of $\boldsymbol{Q}$ and $\boldsymbol{E}$ values of Orosháza soil using common $\boldsymbol{n}$. 
Table 5. The parameters of the model using common $\boldsymbol{n}$

\begin{tabular}{|c|c|c|c|c|c|c|}
\hline $\begin{array}{c}\text { Preliminary } \\
\text { treatments }\end{array}$ & \multicolumn{2}{|c|}{$\begin{array}{c}\text { Orosháza } \\
\mathbf{n}=\mathbf{2 . 5 3}\end{array}$} & \multicolumn{2}{c|}{$\begin{array}{c}\text { Hajdúböszörmény } \\
\mathbf{n}=\mathbf{3 . 6 1}\end{array}$} & \multicolumn{2}{c|}{$\begin{array}{c}\text { Örbottyán } \\
\mathbf{n}=\mathbf{4 . 1 3}\end{array}$} \\
\hline $\mathbf{m g ~ P}$ P/kg soil & $\mathbf{k}$ & $\mathbf{Q}$ & $\mathbf{k}$ & $\mathbf{Q}$ & $\mathbf{k}$ & $\mathbf{Q}$ \\
\hline 0 & 66,96 & 20,65 & 79,70 & 41,50 & 81,63 & 47,73 \\
\hline 10 & 66,84 & 24,93 & 77,00 & 44,46 & 80,26 & 50,40 \\
\hline 20 & 68,96 & 28,69 & 75,06 & 45,46 & 77,15 & 51,80 \\
\hline 40 & 75,97 & 44,74 & 76,18 & 55,30 & 70,00 & 52,57 \\
\hline 80 & 66,64 & 51,66 & 79,49 & 77,12 & 75,12 & 75,87 \\
\hline 160 & 64,01 & 82,15 & 80,00 & 115,84 & 68,15 & 99,94 \\
\hline 320 & 59,69 & 135,88 & 82,01 & 189,30 & 53,13 & 131,48 \\
\hline 640 & 66,45 & 272,05 & 92,71 & 347,07 & 145,67 & 535,76 \\
\hline
\end{tabular}

The $\mathbf{k}$ values (Table 5) obtained during the calculations were also nearly constant within each soil, indicating that the $\mathbf{k}$ and $\mathbf{n}$ parameters of the Freundlich isotherm are constants characteristic of the soil, irrespective of the preliminary treatments, while the $\mathbf{Q}$ values are clearly indicative of the phosphate amount sorbed on the soil as the result of the preliminary treatments.

\section{REFERENCES}

[1] Assimakoupoulos et al. (1986): The effect of previous P aditions on sorption indices of calcareous soils determined with commonly employed methods. - Z. Pflanzenernaehr. Bodenk. 149: 548-560.

[2] Bache, B.W., Williams, E.G. (1971): A phosphate sorption index for soils. - J. Soil Sci. 22: 289-301.

[3] Barrow, N.J. (1974): Effect of previous additions of phosphate on phosphate adsorption by soils. - Soil Sci. 118: 82-89.

[4] Barrow, N.J. (1978): The description of phosphate adsorption curves. - J. Soil Sci. 29: 447-462.

[5] Davis, L.E. (1935): Sorption of phosphates by non-calcareous Hawaian soils. - Soil Sci. 40:129-158.

[6] Fitter, A.H., Sutton, C.D. (1975): The use of the Freundlich isotherm for soil phosphate sorption data. - J. Soil Sci. 26: 241-246.

[7] Hartikainen, H. (1991): Potential mobility of accumlated phosphorus in soil as estimated by the indices of Q/I plots and by extractant. - Soil Sci. 152: 204-209.

[8] Holford, I.C.R., Wedderburn, N.W.M., Mattingly, G.E.G. (1974): A Langmuir two surface equation as a model for phosphete adsorption by soils. - J. Soil Sci. 25: 242-255.

[9] Ryden, J.C. et al. (1977): Mechanism of phosphate sorption by soils and hidrous ferric exide gel. - J. Soil Sci. 28: 72-92

[10] Syers, J.K. et al. (1973): Phosphate sorption by soils evaluated by the Langmuir adsorption equation. - Soil Sci. Soc. Amer. Proc. 37: 358-363.

[11] Taylor, R.W., and Ellis B.G. (1978): A mechanism of phosphate adsorption on soil and anion axchange resin surfaces. - Soil Sci. Amer. J. 42: 432.

[12] Tolner, L., Füleky, Gy. (1995): Determination of the originally adsorbed soil phosphorus by modified Freundlich isotherm. - Commun. Soil Sci. Plant Anal. 26: 1213-1231. 